Article - Human and Animal Health

\title{
Administration of Vaccine Preservative Thimerosal Produces Impairment in Rat Liver
}

\author{
Muhammad Umar ljaz ${ }^{1}$ \\ https://orcid.org/0000-0002-8398-5364
}

Asma Ashraf ${ }^{2}$

https://orcid.org/0000-0001-7026-670X

\section{Hammad Ismail ${ }^{3}$}

https://orcid.org/0000-0002-8008-4595

Muhammad Imran 4

https://orcid.org/0000-0002-3930-5149

Khalid Abdullah Al-Ghanim ${ }^{5}$

https://orcid.org/0000-0003-3700-7911
Fahad Al-Misned ${ }^{5}$

https://orcid.org/0000-0001-7123-6086

Zubair Ahmed ${ }^{5}$

https://orcid.org/0000-0002-2436-0313

\author{
Abdul Samad' \\ https://orcid.org/0000-0003-0688-8189 \\ Mian Nadeem Riaz ${ }^{6}$ \\ https://orcid.org/0000-0002-5151-5982 \\ Shahid Mahboob ${ }^{5 *}$ \\ https://orcid.org/0000-0003-4969-5387
}

Ayesha Rauf ${ }^{1}$

https://orcid.org/0000-0001-5534-5215

${ }^{1}$ University of Agriculture, Department of Zoology, Wildlife and Fisheries, Faisalabad, Pakistan; ${ }^{2}$ Government College University, Department of Zoology, Faisalabad, Pakistan; ${ }^{3}$ University of Gujrat, Department of Biochemistry and Biotechnology, Gujrat, Pakistan; ${ }^{4}$ University of Agriculture, Department of Parasitology, Faisalabad, Pakistan; ${ }^{5}$ King Saud University, College of Science, Department of Zoology, Riyadh, Saudi Arabia. ${ }^{6}$ Texas A\&M University, College Station, Texas, USA.

Editor-in-Chief:Paulo Vitor Farago

Associate Editor: Daniel Fernandes

Received: 2019.12.01; Accepted: 2020.09.10.

*Corresponding: mushahid@ksu.edu.sa (S. M.).

\section{HIGHLIGHTS}

- Toxic effects of thimerosal on rat liver.

- Thimerosal increased the the level of ALT, ALP and AST.

- Activity of CAT, SOD, POD GSH and protein was reduced.

- DNA damage was observed.

Abstract: The present research was planned to analyze the toxic effects of thimerosal on rat liver. Mercury and mercury compounds are universally known toxicants for animals and humans. Thimerosal is widely used in the vaccines as a preservative which contains $49.6 \%$ mercury. Twenty-four adult male albino rats were distributed into four groups $(n=6)$. The first group was considered as a control group. While, second, third and fourth groups were intoxicated with $0.5,10$ and $50 \mu \mathrm{g} / \mathrm{kg}$ thimerosal (i.m.) respectively. After 30 days, rats were slaughtered to analyze the liver tissues. The results of the experiment exposed that thimerosal 
instigated significant $(p<0.05)$ increase in alanine transaminase $(A L T)$, alkaline phosphatase $(A L P)$ and aminotransferase (AST) levels. Catalase (CAT), superoxide dismutase (SOD), peroxidase (POD) activities and Glutathione $(G S H)$ and protein levels were significantly $(p<0.05)$ reduced. Furthermore, significant increases in Hydrogen peroxide $\left(\mathrm{H}_{2} \mathrm{O}_{2}\right)$, thiobarbituric acid reactive substances (TBARS) level and DNA damage was observed. Histopathological study revealed severe damages, e.g. fatty alterations, deterioration of lobular structure and degeneration of nuclei in hepatic tissues of thimerosal treated rats. Results of present investigation revealed that thimerosal induces hepatotoxicity at different levels.

Keywords: thimerosal; reactive Oxygen species; oxidative stress; hepatotoxicity.

\section{INTRODUCTION}

Toxic effects of mercurial compounds have been observed in humans and animals. These compounds damage the central nervous system (CNS), kidneys, immune system and cardiovascular system [1]. Generally, inorganic forms of mercury are associated with renal damage and organic form of mercury induces damage in the nervous system [2].

Thimerosal (sodium ethyl mercury thiosalicylate) contains $49.6 \%$ of mercury $(\mathrm{Hg})$ of its total weight. The use of thimerosal was approved in 1976 by "Drug and Food Administration of United States" and it is being extensively used in vaccines as preservative till the to-date [3]. Thiomersal is also used as a wound disinfectant and preservative agent in medicines [4], and in preparations of different biological products [5]. In 2009, thimerosal was used mostly in anti-flu vaccines to counter the swine influenza [6].

Thimerosal containing vaccines are the central path of mercury exposure in the hospitals [7]. Mercury affects the nervous system of infants and causes several disorders such as speech delay, autism, confusion, learning disabilities and attention deficit hyperactive disorder in them [8]. Thimerosal causes autism spectrum disorder (ASD) and neurodevelopmental disorders [9] High dose of thimerosal containing products has toxic effects [10]. Several studies have also shown impaired binding of secondary messengers and dysregulation of neurotrophin signaling followed by thimerosal exposure [11].

Thimerosal induced damage impacts on epithelial tissues, e.g. contact and conjunctivitis dermatitis have been formerly analyzed [12]. In aqueous salty solution, thiomersal rapidly breaks into ethyl mercury chloride and ethyl mercury hydroxide [13]. Thimerosal can produce the ROS in mammalian cells [14]. Till the date, toxic effects of thimerosal have not been investigated. Therefore, current research was planned to assess the toxic effects of thimerosal on the rat liver.

\section{MATERIAL AND METHODS}

\section{Experimental design}

Thimerosal was purchased from Sigma-Aldrich (Germany). Rats were placed in animal house of the Department of Pharmacology. Twenty-four male rats (Rattus norvegicus), weighing (150-180 g) were selected. Rats were separated into four groups having equal number of rats (six) in each. "Group 1 named as a control group, received $0.9 \%$ of saline through oral gavage. Rats of the group 2 " were treated with $0.5 \mu \mathrm{g} / \mathrm{kg}$ thimerosal through intramuscular injection (i.m.). Group 3: Rats of this group were administrated with thimerosal $10 \mu \mathrm{g} / \mathrm{kg}$ (i.m.). Group 4: Rats of this group received a dose of $50 \mu \mathrm{g} / \mathrm{kg}$ thimerosal (i.m.). Duration of the treatment was thirty days.

\section{Ethical approval}

This experiment was conducted after the approval of ethical committee of the University of Agriculture, Faisalabad (D. No. 2836/ORIC).

\section{Sample collection}

All rats were anesthetized with diethyl ether and dissected on the $31^{\text {st }}$ day of the trial and blood was collected in EDTA tubes. Centrifugation of blood was carried out for $15 \mathrm{~min}$. at $3000 \mathrm{rpm}$ for plasma separation and stored at $-20{ }^{\circ} \mathrm{C}$. Liver of each rat was detached, weighed, washed with ice cold saline and processed for further analysis. Liver parts were also preserved in $10 \%$ formalin solution in glass vials for histopathology and stored in zipper bags at $-20^{\circ} \mathrm{C}$ for antioxidant enzyme analysis. Superfluous rats residual was buried by qualified laboratory technician according to the guidelines of U.S. bio-security agencies. 


\section{Determination of liver function markers}

Levels of functioning markers of liver like AST, ALT and ALP were assessed by means of relevant commercially available abcam diagnostic kits.

\section{Estimation of antioxidant enzyme activity}

CAT and POD activity were evaluated through the procedure of Chance and Maehly [15] after few amendments. Procedure of Kakkar and coauthors [16] was followed to measure the SOD activity. The level of GSH was measured with the spectrophotometric protocol [17].

\section{Estimation of total protein content}

Procedure of Lowry and coauthors [18]. was tailed for the assessment of total protein content in liver tissues.

\section{Estimation of TBARS and $\mathrm{H}_{2} \mathrm{O}_{2}$ level}

TBARS level was evaluated by comprehending the procedure of lqbal [19]. The Hydrogen peroxide $\left(\mathrm{H}_{2} \mathrm{O}_{2}\right)$ level was assessed by following the procedure of Pick and Keisari [20].

\section{Comet Assay:}

DNA damage was assessed by the methodology of Dhawan [21] through neutral comet assay. Pasteurized "slides were immersed in 1\% NMA (Normal melting agarose) and let it set at normal room temperature". In $1 \mathrm{~mL}$ of cold lysis solution, a minor section of liver tissue was placed and crushed in slight fragments and then added $75 \mu$ L LMA (low melting agarose; $1 \%$ ). This prepared solution was spread smoothly over formerly coated slides. These slides were placed in the ice box for almost 8 to 10 min., then the cover slips were amputated and slides were placed again in the ice box and set these to solidify. After that, third coating of LMA was processed and slides were over placed in the lysis mixture for approximately 10 minutes then rested in freezer for two hours. After that staining of slides with ethidium bromide (1\%) was carried out and studied under a fluorescence microscope. Image software (TRITEK) was employed for the assessment of DNA injury level. Parameters such as comet number, tail moment, head length, comet length, olive moment, tail length, \% DNA content in the tail and head were considered for DNA integrity.

\section{Histopathological assessment}

For histopathological assessment, liver tissues were collected and washed with cold normal saline and fixed in neutral buffered formalin solution (10\%) for histopathological examination. Tissues were dehydrated in ascending grades of alcohol $(80 \%, 90 \%$ and $100 \%)$ and embedded in paraffin wax. For the preparations of slides, thin slices of embedded hepatic tissues (almost 4-5 $\mu \mathrm{m}$ ) were cut by using rotary microtome, stretched on slides and stained with hematoxylin/eosin stain. Light microscope (Nikon, 187842, Japan) was used for histopathological study at 40x magnification.

\section{Statistical analysis}

Data was shown as Mean \pm SEM. For the comparison of different groups one-way ANOVA followed by Dunnett's test was applied by using Minitab software. Level of significance was fixed at $p<0.05$.

\section{RESULTS}

\section{Effect of thimerosal on liver function markers:}

Thimerosal administration significantly $(p<0.05)$ increased the hepatic function markers AST, ALP and ALT in treated rats in comparison to the rats of the control group". Thimerosal increased the levels of liver function markers in a dose dependent manner (Table 1). 
Table 1. Effect of thimerosal on protein level and liver function markers ALT, AST and ALP in rats

\begin{tabular}{lccc}
\hline Treatments & ALT $(\mathrm{U} / \mathrm{L})$ & ALP $(\mathrm{U} / \mathrm{L})$ & AST $(\mathrm{U} / \mathrm{L})$ \\
\hline Control & $58.67 \pm 3.28^{\mathrm{a}}$ & $65.00 \pm 2.35^{\mathrm{a}}$ & $49.33 \pm 2.90^{\mathrm{a}}$ \\
Thimerosal $(0.5 \mu \mathrm{g} / \mathrm{kg})$ & $85.33 \pm 4.25^{\mathrm{b}}$ & $92.33 \pm 2.37^{\mathrm{b}}$ & $75.33 \pm 3.17^{\mathrm{b}}$ \\
Thimerosal $(10 \mu \mathrm{g} / \mathrm{kg})$ & $93.33 \pm 4.25^{\mathrm{b}}$ & $94.00 \pm 2.16^{\mathrm{b}}$ & $84.67 \pm 2.60^{\mathrm{c}}$ \\
Thimerosal $(50 \mu \mathrm{g} / \mathrm{kg})$ & $188.7 \pm 9.49^{\mathrm{c}}$ & $113.3 \pm 1.96^{\mathrm{c}}$ & $158.3 \pm 4.40^{\mathrm{d}}$ \\
\hline
\end{tabular}

Means that do not share similar letters are significantly different.

\section{Effects of thimerosal on antioxidant enzyme activity and total protein content:}

Thimerosal administration disturbed the antioxidant enzyme activity. CAT, POD, SOD activities and GSH level were significantly $(p<0.05)$ reduced in the thimerosal administrated groups when compared with the control group. Thimerosal decreased the activities and level of these anti-oxidant enzymes in a dose dependent manner. Moreover, the protein content in liver tissues significantly $(p<0.05)$ reduced in a dose dependent means in all the treated groups compared to the control group (Table 2).

Table 2. Effect of thimerosal on antioxidant enzymes CAT, POD, SOD, GSH and total protein content in hepatic tissues

\begin{tabular}{lccccc} 
Treatments & $\begin{array}{c}\text { CAT }(\mathrm{U} / \mathrm{mg} \\
\text { protein) }\end{array}$ & $\begin{array}{c}\text { POD }(\mathrm{U} / \mathrm{mg} \\
\text { protein) }\end{array}$ & $\begin{array}{c}\text { SOD }(\mathrm{U} / \mathrm{mg} \\
\text { protein })\end{array}$ & $\begin{array}{c}\mathrm{GSH}(\mu \mathrm{M} / \mathrm{g} \\
\text { tissue })\end{array}$ & $\begin{array}{c}\text { Protein } \\
\text { content }(\mathrm{mg} / \mathrm{g})\end{array}$ \\
\hline Control & $7.53 \pm 0.11^{\mathrm{a}}$ & $4.43 \pm 0.11^{\mathrm{a}}$ & $8.43 \pm 0.12^{\mathrm{a}}$ & $16.62 \pm 0.19^{\mathrm{a}}$ & $5.02 \pm 0.05^{\mathrm{a}}$ \\
Thimerosal $(0.5 \mu \mathrm{g} / \mathrm{kg})$ & $6.23 \pm 0.07^{\mathrm{b}}$ & $3.85 \pm 0.03^{\mathrm{b}}$ & $5.87 \pm 0.04^{\mathrm{b}}$ & $14.80 \pm 0.09^{\mathrm{b}}$ & $4.39 \pm 0.02^{\mathrm{b}}$ \\
Thimerosal $(10 \mu \mathrm{g} / \mathrm{kg})$ & $6.07 \pm 0.04^{\mathrm{b}}$ & $3.71 \pm 0.02^{\mathrm{b}}$ & $3.65 \pm 0.03^{\mathrm{c}}$ & $14.07 \pm 0.07^{\mathrm{b}}$ & $4.27 \pm 0.03^{\mathrm{b}}$ \\
Thimerosal $(50 \mu \mathrm{g} / \mathrm{kg})$ & $4.55 \pm 0.17^{\mathrm{c}}$ & $3.03 \pm 0.03^{\mathrm{b}}$ & $2.78 \pm 0.01^{\mathrm{d}}$ & $12.02 \pm 0.05^{\mathrm{c}}$ & $3.97 \pm 0.04^{\mathrm{c}}$ \\
\hline
\end{tabular}

Means that do not share similar letters are significantly different

\section{Impacts of thimerosal on $\mathrm{H}_{2} \mathrm{O}_{2}$ and TBARS:}

$\mathrm{H}_{2} \mathrm{O}_{2}$ and TBARS level were significantly $(p<0.05)$ increased in thimerosal administrated "rats in comparison to control. Thimerosal increased the levels of TBARS and $\mathrm{H}_{2} \mathrm{O}_{2}$ in a dose dependent manner" (Table 3).

Table 3. Effects of thimerosal on TBARS and $\mathrm{H}_{2} \mathrm{O}_{2}$ level in hepatic tissues

\begin{tabular}{lcc}
\hline Treatments & $\mathrm{H}_{2} \mathrm{O}_{2}(\mathrm{nM} / \mathrm{min} / \mathrm{mg}$ protein $)$ & TBARS $(\mathrm{nm}$ TBARS $/ \mathrm{min} / \mathrm{mg}$ tissue $)$ \\
\hline Control & $1.69 \pm 0.04^{\mathrm{a}}$ & $15.57 \pm 0.61^{\mathrm{a}}$ \\
Thimerosal $(0.5 \mu \mathrm{g} / \mathrm{kg})$ & $2.19 \pm 0.06^{\mathrm{b}}$ & $17.84 \pm 0.59^{\mathrm{b}}$ \\
Thimerosal $(10 \mu \mathrm{g} / \mathrm{kg})$ & $2.41 \pm 0.01^{\mathrm{b}}$ & $18.14 \pm 0.26^{\mathrm{b}}$ \\
Thimerosal $(50 \mu \mathrm{g} / \mathrm{kg})$ & $2.92 \pm 0.02^{\mathrm{c}}$ & $21.91 \pm 0.14^{\mathrm{c}}$
\end{tabular}

Means that do not share similar letters are significantly different.

\section{Effect of thimerosal on comet parameters:}

Current findings indicated that thimerosal produced the DNA damages in liver cells. Tail length, comet length, olive moment, tail moment and \% DNA in the tail remarkably $(p<0.05)$ enhanced in comparison to control. Moreover, \% DNA in head and head length were substantially $(p<0.05)$ reduced in thimerosal treated groups while compared to control (Table 4, Figure 2). 
Table 4. Effects of thimerosal on comet parameters of hepatic cells in rat.

\begin{tabular}{lcccc}
\hline Groups & Control & Thimerosal $(0.5 \mu \mathrm{g} / \mathrm{kg})$ & Thimerosal $(10 \mu \mathrm{g} / \mathrm{kg})$ & Thimerosal $(50 \mu \mathrm{g} / \mathrm{kg})$ \\
\hline No. of comets & $28.66 \pm 1.20^{\mathrm{a}}$ & $35.13 \pm 1.16^{\mathrm{b}}$ & $39.85 \pm 0.85^{\mathrm{c}}$ & $50.77 \pm 1.71^{\mathrm{d}}$ \\
Comet length & $40.2 \pm 1.14^{\mathrm{a}}$ & $47.4 \pm 0.83^{\mathrm{b}}$ & $52.14 \pm 1.02^{\mathrm{c}}$ & $60.72 \pm 1.15^{\mathrm{d}}$ \\
Tail length & $5.98 \pm 0.07^{\mathrm{a}}$ & $6.33 \pm 0.01^{\mathrm{b}}$ & $6.95 \pm 0.03^{\mathrm{b}}$ & $07.32 \pm 0.05^{\mathrm{c}}$ \\
Head length & $38.22 \pm 0.64^{\mathrm{a}}$ & $30.22 \pm 0.54^{\mathrm{b}}$ & $29.62 \pm 0.43^{\mathrm{b}}$ & $24.44 \pm 0.27^{\mathrm{c}}$ \\
$\%_{\text {in tail }}^{\mathrm{b}}$ & $6.02 \pm 0.08^{\mathrm{a}}$ & $10.11 \pm 0.12^{\mathrm{b}}$ & $13.32 \pm 0.54^{\mathrm{c}}$ & $20.55 \pm 0.81^{\mathrm{d}}$ \\
\% in head & $93.97 \pm 0.08^{\mathrm{a}}$ & $89.88 \pm 0.12^{\mathrm{b}}$ & $86.01 \pm 0.13^{\mathrm{b}}$ & $79.45 \pm 0.81^{\mathrm{c}}$ \\
Olive moment & $2.18 \pm 0.04^{\mathrm{a}}$ & $2.68 \pm 0.01^{\mathrm{a}}$ & $3.04 \pm 0.03^{\mathrm{b}}$ & $3.24 \pm 0.03^{\mathrm{b}}$ \\
Tail moment & $0.69 \pm 0.00^{\mathrm{a}}$ & $1.21 \pm 0.01^{\mathrm{b}}$ & $1.35 \pm 0.01^{\mathrm{b}}$ & $1.95 \pm 0.03^{\mathrm{c}}$ \\
\hline
\end{tabular}

Means that do not share similar letters are significantly different.

\section{Effect of thimerosal on liver histology}

Thimerosal induced morphological damages in rat liver are displayed in Figure 1. Rats of control group exhibited standard structural patterns of liver with normal sinusoids and central veins as demonstrated in Figure 1A. But Thimerosal intoxication resulted in the serious liver impairments such as a remarkable increase in the fat deposits, degenerated structure of the lobules and infiltration of inflammatory cells with dilated sinusoids in a dose dependent manner as shown in Figures $1 \mathrm{~B}, \mathrm{C}, \mathrm{D}$.

Thimerosal, a mercury derived compound, is made up of ethyl mercury and thiosalicylic acid. It is used in vaccines as a preservative [22]. Liver confronts the toxicants that reach in the liver, portal vein through the digestive system. Liver functions can be disturbed due to injury caused by severe or long-lasting exposure to toxicants [23]. The present study was conducted to assess biochemical, histopathological and DNA damage in liver due to thimerosal.
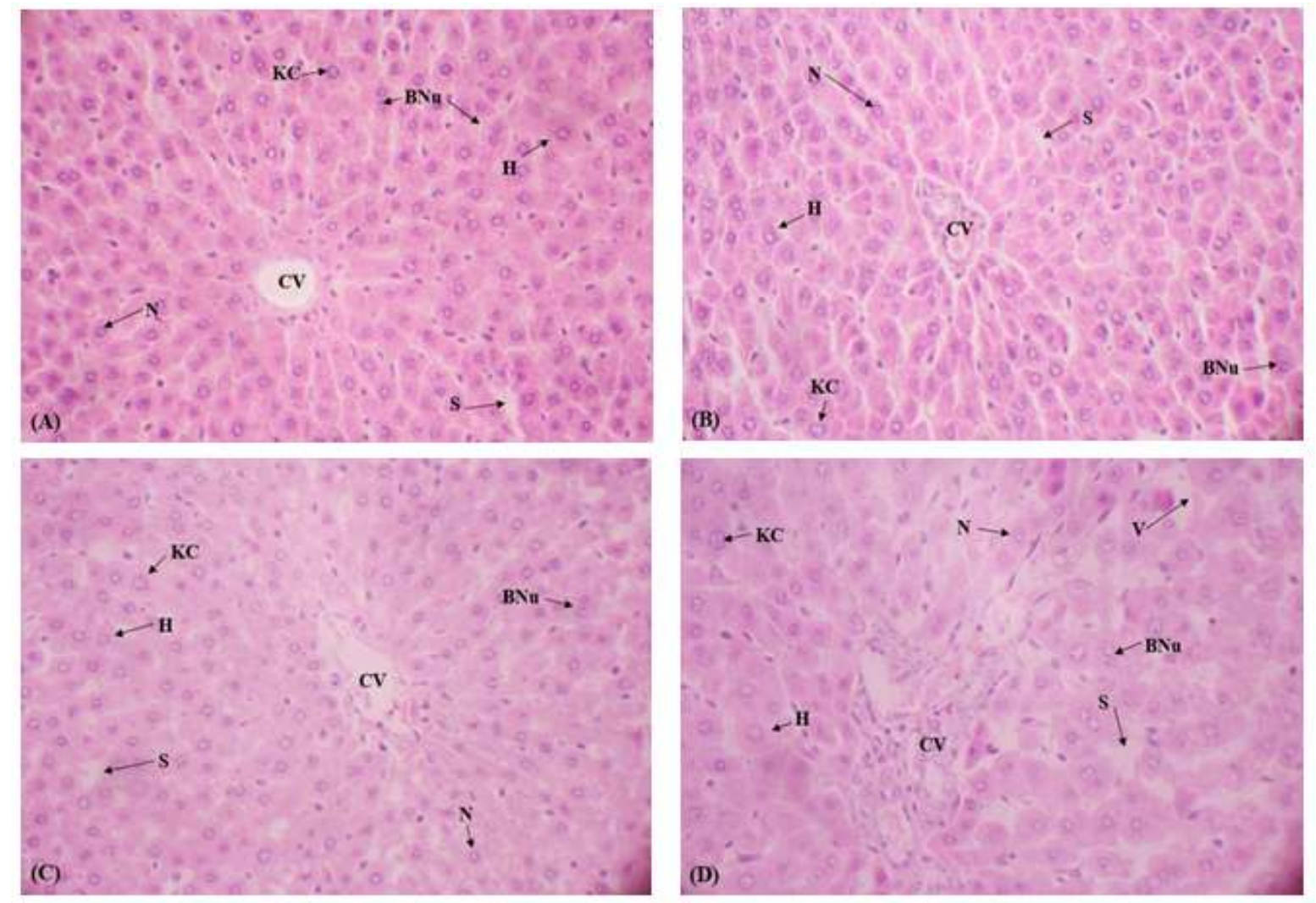

Figure 1. Effects of thimerosal on liver histology (40x, H\&E). A) Control group. B) Thimerosal $(0.5 \mu \mathrm{g} / \mathrm{kg})$. C) Thimerosal $(10 \mu \mathrm{g} / \mathrm{kg})$. D) Thimerosal $(50 \mu \mathrm{g} / \mathrm{kg})$. CV; Central venule, S; Sinusoids, H, Hepatocytes; KC, Kupffer cells; N, Nucleus; $\mathrm{CNe}$, Centrilobular necrosis; BNu, binucleated; $\mathrm{V}$, vacuoles. 

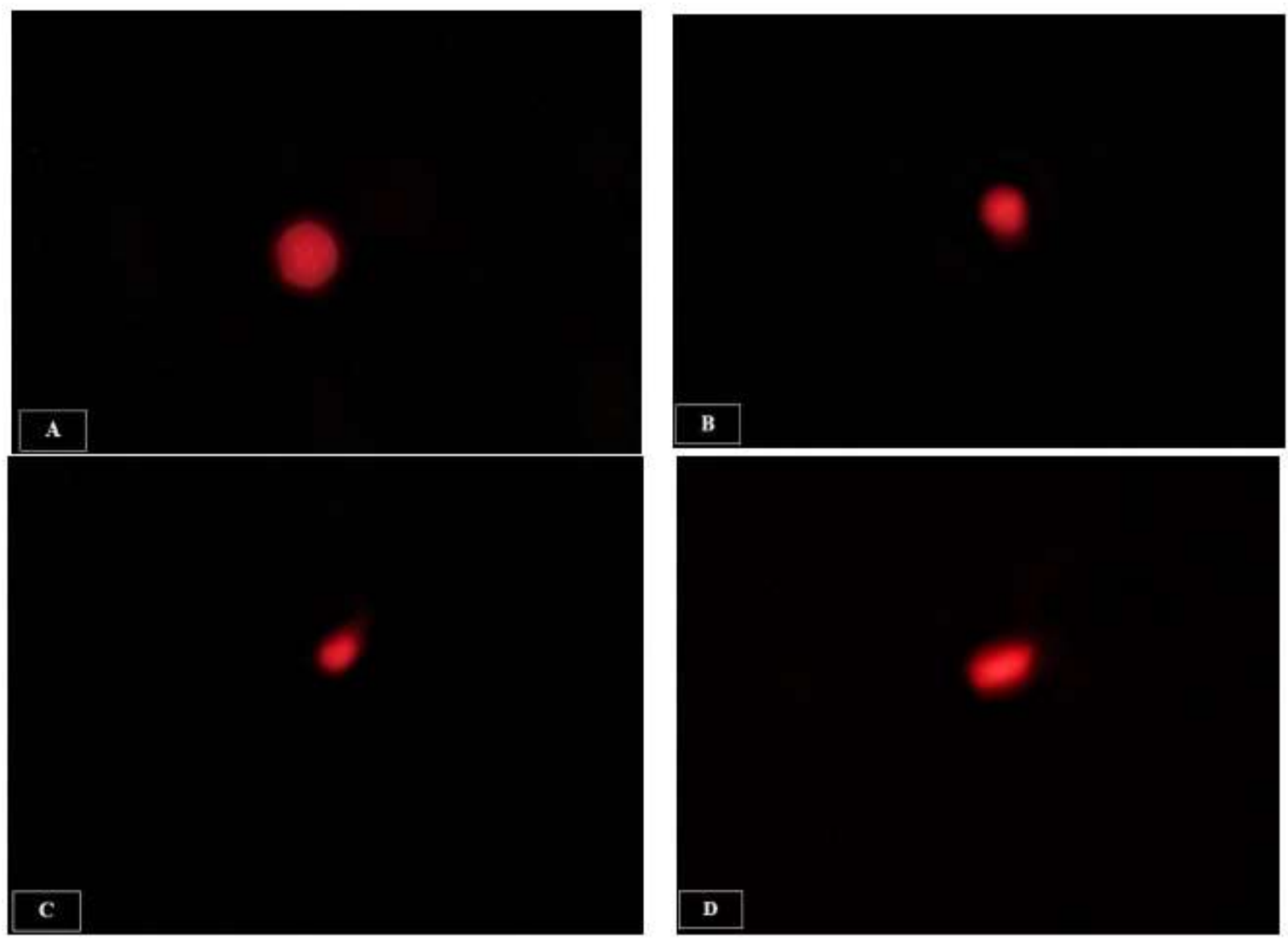

Figure 2. Fluorescence photomicrograph of liver cells and genotoxic outcome of thimerosal (A) Control (B) Thimerosal $(0.5 \mu \mathrm{g} / \mathrm{kg})$ treated $(\mathbf{C})$ Thimerosal $(10 \mu \mathrm{g} / \mathrm{kg})$ treated (D) Thimerosal $(50 \mu \mathrm{g} / \mathrm{kg})$ treated.

\section{DISCUSSION}

AST, ALT and ALP represents the measurable liver function markers. In current research, a remarkable increase in serum biomarkers was observed in thimerosal treated rats, hereafter evincing the fact that due to structural damage of hepatocytes, enzymes were discharged into the bloodstream instead of residing in the cytoplasm. The unusual increase of these enzymes in blood is always associated with hepato-necrosis [24]. This can be evidently observed in the histopathology of thimerosal treated groups (Figures $1 \mathrm{~b}, \mathrm{c}, \mathrm{d}$ ) in which cellular infiltration, degeneration and colossal necrosis of hepatocytes happened afterwards several cytosolic marker enzymes of liver were moved into the blood stream [25]. The significant increases in these markers confirmed that liver performance was disturbed, which was further confirmed by acute histopathological alterations.

CAT, SOD and POD (antioxidant enzymes) are essential regulators of oxidative stress in the cell. SOD changes superoxide to $\mathrm{H}_{2} \mathrm{O}_{2}$ and participates as an initial defense line against its lethal impacts [26]. CAT deteriorates $\mathrm{H}_{2} \mathrm{O}_{2}$ into water and oxygen and protects the tissues from damage due to lipid peroxidation in the biological system. In this research, activities of anti-oxidant enzymes like CAT, POD, SOD and level of GSH in liver tissues were remarkably reduced. Reduced activities of antioxidant enzymes, level of GSH and protein in serum showed that the acute liver damages were induced due to thimerosal. It seems that the administration of thimerosal causes oxidative stress in the liver via the production of free radicals. According to Sharpe and coauthors [27], decrease in the antioxidant enzyme levels leads to oxidative stress and thus cell becomes unable to detoxify ROS produced within the cell. The overwhelming production of free radicals in turn further suppresses the activities of antioxidant enzymes. In this experiment, decrease in total protein content showed that the injuries were due to mercury containing compounds [28].

Thimerosal increased $\mathrm{H}_{2} \mathrm{O}_{2}$ formation, accompanied by amplified peroxidation of mitochondrial lipids, which leads to oxidative stress. Hence, mercury containing compound are known to elevate hydrogen peroxide due to increase of ROS. Thimerosal increased the level of the TBARS. Thimerosal exposure produced free radicals that caused damage in lipids, proteins and DNA in the body. Hepatic tissues are extremely susceptible to the toxic chemicals which results in hepatic cirrhosis which leads to death. Peroxidation of the polyunsaturated fatty acids may lead to increased levels of TBARS which is the final 
product of lipid peroxidation and considered as oxidative stress biomarker [29]. TBARS are involved in the destruction of the membrane system of the cell and fusion of extremely reactive $\mathrm{H}_{2} \mathrm{O}_{2}$ which increases its capability to react with proteins and DNA.

ROS production in the cells can instigate deterioration in cell membrane and DNA damage that can be authenticated by examining histopathology and comet assay. Comet assay has turned out to be a basic technique to measure DNA impairment [30]. DNA is affected by several toxins whose commotion escorts to genotoxic consequences [31] and breakdown of double or single strand might also occur in DNA by disturbing its unified form. In the present research, comet assay was operated for the evaluation of damage in various DNA parameters together with tail length, head length, comet length, \% DNA in the head and \%DNA in tail moment. The rise in the tail length, tail moment, comet length and \% DNA in tail samples of liver cells were observed when treated with thimerosal. Thimerosal raised the constrictions replicate DNA breakdowns and destructions of the membrane system of liver cells. Corresponding toxicity enhanced the liver damages and functional irregularities, though \% DNA in head remained reduced within thimerosal treated rats [32]. Thimerosal caused DNA damage in liver cells is conscientious for DNA relocation from comet head to tail, consequently escalating the \% DNA in tail, tail moment as well as tail length as reported in Ali and coauthors [33] against standard toxin.

In the current study, blockage of hepatoportal blood vessels, blockage of central vein and fatty alterations in portal tract of treated rats demonstrated the toxic effects of thimerosal compound. Damage in liver histology was in line with elevation in hepatic marker enzyme which shows cellular damage of hepatocytes [34]. These damages in liver tissues are may be due to lipid peroxidation, which caused tissue degeneration and deterioration of cell membranes as observed in standard toxin intoxication [33].

\section{CONCLUSION}

The consequences of this study exhibited that thimerosal at its low $(0.5 \mu \mathrm{g} / \mathrm{kg})$, medium $(10 \mu \mathrm{g} / \mathrm{kg})$ and higher $(50 \mu \mathrm{g} / \mathrm{kg})$ doses induced oxidative stress and disturbed the liver in a dose dependent manner and highest damage was observed at $50 \mu \mathrm{g} / \mathrm{kg}$. The results of the present research propose novel discernments about possible hazards of thimerosal exposure to animals and might additionally impart basic data regarding to the potential hazardous effects of thimerosal on human health. Thus, the use of thimerosal as animal and human vaccine preservative should be of great concern, specifically tell the efficient risk evaluation. More studies are required to investigate the molecular basis of these changes both in vivo and in vitro, which will help to identify that how thimerosal influences the physiology of various tissues within the body.

Acknowledgments: The authors express their sincere appreciation to the Research Supporting Project No. RSP2021-93 the King Saud University, Riyadh, Saudi Arabia.

Conflicts of Interest: The authors declare no conflict of interest.

\section{REFERENCES}

1. Clarkson TW, Magos L, Meyers GJ. Human exposure to mercury: the three modern dilemmas. J Trace Elem Exp Med. 2003;16:321-43.

2. Clarkson TW, Magos L. The toxicology of mercury and its chemical compounds. Crit Rev Toxicol, 2006 Sep;36(8):609-62.

3. Stratton K, Gable A, McCormick MC. Institute of Medicine (US) Immunization Safety Review Committee. Immunization safety review: thimerosal-containing vaccines and neurodevelopmental disorders. National Academies Press (US); 2001.

4. Magos L. Review on the toxicity of ethylmercury, including its presence as a preservative in biological and pharmaceutical products. J Appl Toxicol. 2001 Jan-Feb;21(1):1-5.

5. Geier DA, Geier MR. A prospective study of mercury toxicity biomarkers in autistic spectrum disorders. J Toxicol Environ Health A. 2007 Oct;70(20):1723-30.

6. Trumpler S, Meermann B, Nowak S Buscher W, Karst U, Sperling M. In vitro study of thimerosal reactions in human whole blood and plasma surrogate samples. J Trace Elem Med Biol, Apr;28(2):125-30.

7. Bigham M, Copes R. Thiomersal in vaccines: balancing the risk of adverse effects with the risk of vaccinepreventable disease. Drug Saf. 2005;28(2):89-101.

8. Kidd PM. Autism, an extreme challenge to integrative medicine. Part 1: The knowledge base. Altern Med Rev. 2002 Aug;7(4):292-316. 
9. Adamson P, Auty D, Ayres D, Backhouse C, Barr G, Betancourt M, Bishai M, Blake A, Bock G, Boehnlein D. Improved search for muon-neutrino to electron-neutrino oscillations in MINOS. Phys. Rev. Lett. 2011 Oct; $107: 181802$.

10. Pichichero ME, Cernichiari E, Lopreiato J, Treanor J, Mercury concentrations and metabolism in infants receiving vaccines containing thiomersal: a descriptive study. Lancet. 2002 Nov;360(9347):1737-41.

11. Vanlingen S, Sipma H, De Smet P, Callewaert G, Missiaen L, De Smedt H, Parys JB. Modulation of inositol 1, 4, 5-trisphosphate binding to the various inositol 1, 4, 5-trisphosphate receptor isoforms by thimerosal and cyclic ADPribose. Biochem Pharmacol. 2001 Apr;61(7):803-9.

12. Garner LA Contact dermatitis to metals. Dermatol Ther. 2004;17(4):321-7.

13. Tan M, Parkin J. Route of decomposition of thiomersal (thimerosal). Int J Pharm. 2000 Nov;208(1-2):23-34.

14. Kim E, Kim JH, Kim HS, Ryu SH, Suh PG. Thimerosal stimulates focal adhesion kinase and cytoskeletal changes by redox modulation. Biochim Biophys Acta. 2002 Dec;1593(1):9-15.

15. Chance B, Maehly AC. Assay of catalasenand peroxidases. Methods in Enzymol 1995 Nov;11:755-64.

16. Kakkar P, Das B, Viswanathan PN. A modified spectrophotometric assay of superoxide dismutase. Indian J Biochem Biophysi, 1997;21:130-2.

17. Jollow DJ, Thorgeirsson SS, Potter WZ, Hashimoto M, Mitchell JR. Acetaminophen-induced hepatic necrosis. VI. Metabolic disposition of toxic and nontoxic doses of acetaminophen. Pharmacology. 1974;12(4-5):251-71.

18. Lowry OH, Rosebrough NJ, Farr AL, Randall RJ. Protein measurement with the Folin phenol reagent. J Biol Chem. 1951 Nov;193(1):265-75.

19. Iqbal M, Sharma SD, Zadeh HR, Hassan N, Abdullah M, Athar M, Glutathione. metabolizing enzymes and oxidative stress in Ferric nitilotrilotriacetate (Fe-NTA) mediated hepatic injury. Redox Rep. 1996 Jul;23:85-91.

20. Pick E, Keisari, Y. Superoxide anion and hydrogen peroxide production by chemically elicited peritoneal macrophages-induction by multiple nonphagocytic stimuli. Cellu Immunol, 1981 Apr; 59:301-18.

21. Dhawan A, Bajpayee M, Parmar D. Comet assay: a reliable tool for the assessment of DNA damage in different models. Cell Biol Toxicol. 2009 Feb;25(1):5-32.

22. Bigham M, Copes R. Thiomersal in vaccines: balancing the risk of adverse effects with the risk of vaccinepreventable disease. Drug Saf. 2005;28:89-101.

23. Adewusi EA, Afolayan AJ. A review of natural products with hepatoprotective activity. J Med Plants Res. 2010 Oct;:4:1318-34.

24. Eidi A, Mortazavi P, Moghadam JZ, Mardani PM. Hepatoprotective effects of Portulaca oleracea extract against CCl4-induced damage in rats. Pharm Biol, 2015 Dec;53:1042-51.

25. Khan RA, Khan MR, Sahreen S. Attenuation of $\mathrm{CCl} 4$-induced hepatic oxidative stress in rat by Launaea procumbens, Exp Toxicol Pathol, 2013 Mar;65:319-26.

26. Liochev SI, Fridovich I. Mechanism of the peroxidase activity of $\mathrm{Cu}, \mathrm{Zn}$ superoxide dismutase. Free Radic Biol Med, 2010 Jun;48(12):1565-9.

27. Sharpe MA, Livingston AD, Baskin DS. Thimerosal-derived ethylmercury is a mitochondrial toxin in human astrocytes: possible role of fenton chemistry in the oxidation and breakage of mtDNA. J Toxicol. 2012 May;373678.

28. Samipillai S, Elangomathavan R, Ramesh S, Jagadeesan G. Effect of taurine and glutathione on mercury toxicity in liver tissue of rats. Recent Res Sci Technol. 2009 Oct;1:243-9.

29. Ayala A, Mario F, Munoz S. Arguelles Lipid Peroxidation: Production, Metabolism, and Signaling Mechanisms of Malondialdehyde and 4-Hydroxy-2-Nonenal. Oxid Med Cell Longev, 2014 Mar;360438.

30. Jagetia GC, Rao SK. The Indian medicinal plant giloe (Tinospora cordifolia) induces cytotoxic effects by damaging cellular DNA in HeLa cells: a comet assay study. Trends Green Chem, 2015 Nov;1:1-6.

31. Bas H, Pandır D, Kalender S. Furan-induced hepatotoxic and hematologic changes in diabetic rats: the protective role of lycopene. Arch Ind Hyg Toxicol 2016 Oct;67:194-203.

32. Abdul-Hamid M, Salah M. Lycopene reduces deltamethrin effects induced thyroid toxicity and DNA damage in albino rats. J Basic Appl Zool. 2013 Aug;66:155-63.

33. Ali S, Khan MR, Sajid M. Protective potential of Parrotiopsis jacquemontiana (Decne) Rehder on carbon tetrachloride induced hepatotoxicity in experimental rats. Biomed Pharmacothe. 2017 Sep;95:1853-67.

34. Ibegbu AO, Ayuba M, Animoku AA, Daniel B, Sadeeq AA, Peter A, Hamman WO, Umana UE, Musa SA. Effect of Ascorbic Acid on Mercury-Induced Changes on the Liver in Adult Wistar Rats. J Dent Med Sci. 2014 Oct;13:10-6.

(C) 2021 by the authors. Submitted for possible open access publication under the terms and conditions of the Creative Commons Attribution (CC BY NC) license (https://creativecommons.org/licenses/by-nc/4.0/). 